UDC 378.22:78

DOI https://doi.org/10.32840/1992-5786.2020.70-1.10

O. A. Bukhniieva

$\mathrm{PhD}$, Associate Professor of Music and the Fine Arts Department of Izmail State University of Humanities

L. D. Bankul

Associate Professor of Music and the Fine Arts Department of Izmail State University of Humanities

\title{
SOME METHODICAL ASPECTS OF STUDENTS' MUSIC EDUCATION AT THE CURRENT STAGE
}

The article deals with the problem of students' musical education at the current stage in the context of performing the tasks of reforming art and pedagogical education. This problem is raised during the study of the course "Methodology of Music Teaching" in higher education institution. This course is introduced into the educational process of specialization 014.13 Secondary education. Musical art. It is considered the process of understanding the worldview value of musical art in the light of modern methodological aspects of music pedagogy. Also it is considered the process of comprehending the adequacy of modern perception of musical art by high school students. It is proved the importance of the synthesis of musical education's established traditions with the need to move to a fundamentally new method of music teaching. Nowadays, this method requires the teacher to transform the system of methodical thinking. Also it is proved students' understanding of the features of modern musical language and means of musical expression; understanding musical intonation as one of the most effective means of discovering the artistic image of a work. There are analyzed and determined the positive influence of classical music on the formation of the modern student's special qualities; the formation of a system of musical, artistic and human values as determinants of the attitude of the individual to the modern world and corresponding to certain values of the behavior and life in the world.

Artistic and informative competence is revealed as one of the most important ways of the artistic and professional level of the teacher. This competence is revealed on the basis of the analysis of some methodical aspects of students' musical education at the current stage

It is established that the main tasks of an innovative approach to the methodological aspects of students' music teaching. Its task is to constantly search for and introduce new maximally effective technologies of musicpedagogical didactics. The realization of modern music-pedagogical aspects of students' education depends on one important condition. This condition is an innovative potential of the music art teacher. This potential consists in the ability to create, perceive, innovate and get rid of outdated in time, pedagogically inappropriate teaching methods.

Key words: contemporary musical and pedagogical aspects of teaching, methods of musical teaching, musical pedagogy.

Articulation of issue. Musical education of students is aimed at preserving the developed and tested forms and methods of work with high school students. But there is a constant search in XXI century for new innovative forms, methods, newest pedagogical technologies of content and types of educational activity. The question of the place and role of music art in the life of a modern student gets more urgent. Also it is major nowadays the importance and influence of music as an educational tool on the aesthetically-emotional and spiritual development of the younger generation; the elucidation of the principles and means of organizing the process of modern musical education, the substantiation of the necessary methods of updating this work.

Analysis of recent researches and publications. Pedagogical science has a wealth of experience in clarifying the outlined issues. Thus, the general pedagogical problems of musical education of students are covered in the scientific works of L. Vyhotskyi [3], I. Zyazyun [5], O. Rostovskyi [11], E. Bielkina [6], I. Rudenko [6]. The works of authors in the field of music pedagogy investigate the issues related to clarification of the essence of music teaching, the influence of musical art on the aesthetic development of students, their assimilation of artistic culture, musical folklore, etc. (O. Haydamaka [6], O. Rostovskyi [11], L. Masol [6], E. Pecherska [10] and others). Scientific and methodological studies have described a considerable range of methods and technologies of students' music education (E. Ablullin [1], L. Masol [6], O. Oleksiuk [9], O. Rudnytska [12], V. Cherkasov [13], L. Shkoliar [8] and others).

In our opinion, more in-depth study of modern aspects of the methodology of students' music teaching and the application of the most progressive of them in the practice at school life. 
The purpose of the article is to find out some methodical aspects of music teaching at the present stage of development of music pedagogy methodology.

Statement of basic materials. The leading task of musical education, that is, music pedagogy, has always been and remains the artistic and creative development of students. The teacher should develop students' sensitivity to music, introduce them to the world of love and kindness, and reveal a lifegiving source of human feelings and natural beauty in music. Skillful and purposeful educational work in high school is extremely important in this process. Its quality is primarily due to the problems associated with finding effective ways, defining the ultimate goals and methods of students' music teaching, choosing a modern curriculum, etc.

It is given the following definition of the teaching method in the Ukrainian pedagogical dictionary (edited by S. Honcharenko): the method (in Greek "Methodos" - way of perception) teaching is a way of orderly interrelated activity of teachers and students aimed at solving educational tasks [4, p. 250].

We can determine that the established ways of students' music teaching are not always effective. The problems which arise in this way lie not so much in the plane of practice, but in terms of their theoretical understanding. The methodological ambiguity of the basic concepts of music pedagogy is becoming more and more evident. Hence, we have different interpretations of musical and pedagogical aspects, different vision of problems.

From the philosophical point of view of understanding the essence of music teaching is the following: the provisions regarding the need to achieve aesthetic enjoyment of the perception of works of art (Aristotle). Hegel's views on such specific patterns of music as its temporal nature, the dialectical connection of the means of artistic expression are of particular importance. $\mathrm{H}$. Plekhanov's opinion says that art expresses ideas and moral-aesthetic norms of the attitude of a person to reality not in a direct but indirect way. It is means, the importance of the ability of art to activate the emotional-evaluation, artisticcognitive and other reactions of humanity [8, p. 24].

Modern philosophers point to the growing role of art in personality's formation, strengthening, its influence on the mass consciousness. The development of mass communication, digitization, information has significantly pushed the boundaries of the penetration of the art in people's lives. Nowadays, the great deal of information has made it possible to find yourself virtually in many art galleries, theaters, concert halls, etc. It helps students to develop their perception of musical art. It is important to think that the functions of the most sophisticated work of art are realized only in the presence of an appropriate culture of artistic perception [2, p. 75].
There is a paradox of the intricate connection between art and education. Since the whole of the cultural history shows that art really educates only when it is not didactic-directed, moralizing, preaching. The art reproduces rich and unexpected collisions of life and time in living artistic images [2, p. 112]. Musical art is a way of holistic education of the spiritual world of the individual, not just artistic or aesthetic education.

According to I. Ziaziun, a very important aspect of the music teaching methodology is the manifestation of the creative intuition of the teacher. The intuition is not only connected with the birth of new information, but involves the use of previously accumulated experience [5, p. 124].

According to $\mathrm{V}$. Medushevskyi, the general scientific basis of music education is, first and foremost, the fundamental premises of such leading concepts of modern musicology as: the concept of intonationfable and communicative nature of music, artistic and musical activity as a creative process, the interconnection of social and personal in the process of musical perception [7, p. 5].

Musicologists point to an important aspect of music learning - to teach students the understanding of music as an art of intonational meaning. Such meaning that functions in the general system of aesthetic attitudes. The intonational affiliation of music to each era determines the various communicative possibilities of the musical art. Hence, the logical approach to musical perception as artistic communication of students with musical art. In pedagogical terms, this approach determines the great number of communicative possibilities of musical art of the modern world. As well as the teachers' attention to the student the ability of emotional and imaginative perception of musical art with a focus on expanding the intonational experience of students.

An important aspect of music pedagogy may be B. Asafiev's thesis on the music art integrated combination. There are inextricably linked the creation, performance and perception of music. The conclusion about the deep community of all kinds of musical activities directs the teacher to the formation of a modern updated musical thinking, notably, the ability to art-musical knowledge of modern reality [2, p. 54].

Important for music pedagogy is V. Medushevsky's conclusion that there are two layers of content in the musical work. These are clearly expressed meaning and deep sociocultural interpretations. Nowadays, they are filled with modernly updated paradigms. The explicit expressions are filled with the emotional form of music. Their perception is based on the semiotic basis of musical culture (system of genres, styles, languages). Depths of value are aroused by the artistic world of the work, arising from the interaction of the closer content 
of music with the historical context. Such a dialectic of the closer and further meaning of the content is a source of limitless possibilities for manifesting the individuality of the listeners [7].

The adequacy aspect of musical perception becomes methodologically important. If it is adequate to consider the perception, which is characterized by the completeness of the plan of the composer and performer, then not every student can rise to this level. Music scholars emphasize that the problem of adequacy is related not only to the quality level of perception, but also to its compliance with modern social assessments and norms. Adequate contemporary perception is the comprehension of musical art in the light of contemporary musicallinguistic, genre, stylistic and spiritual-value principles of culture.

In order for the modern perception to become adequate, the listener must understand the work and reveal its personal meaning. He must do it on the basis of mastering the modern musical language, genre-stylistic ideas, and the system of artistic values. However, it depends on the personal system of aesthetic needs of the modern student that will attract the attention of the listener in this work.

Modern methods of music teaching use methods that activate students' perception of music. But we should start from the fact that there are no mandatory and compulsory methods of musical work perception. Their declaration, for the most part, gives students a spontaneous opposition to complex works. Therefore, an important factor in the musical art influence on students is the creation of conditions for the independent discovery of contemporary aesthetic values of works, not just adaptation to previously established values.

Nowadays, there is one problem of students' music education. The problem results in insufficient quantity of conceptual works in modern music pedagogy. This refers to such works that are not only full of understanding the requirements of modern times and analytics of observations, but also full of generalizing ideas.

In our opinion, the most striking of the last decades is D. Kabalevskyi musical-pedagogical concept and those scholars who adapt D. Kabalevskyi methodology to the present level of perception of musical art by students. D. Kabalevskyi pedagogical concept absorbed the world and national pedagogy's achievements. This concept is distinguished by scientific validity and orientation to the formation of the human's spiritual world by means of music. In the XX-XXI centuries, there is an even greater development of music-pedagogical systems, techniques. The authors of such systems and techniques are well-known musicians, pedagogues, composers (L.Vynohradov "Music as an activity of communication", E. Hordon "Musical audiation", Sh. Suzuki "Talents education"), as well as concepts P. Hauve, L. Shkolyar, V. Kiryushyna, I. Manakova and others. Here are some of them.

The method of thinking about music, aimed at personal, creative and individual assimilation of spiritual values by students. D. Kabalevsky wrote: "It is important for new issues to be solved, by means of short interviews with the teacher. Each interview should have three points in common: the first is a clearly formulated task by the teacher; the second is a consistent solution of this task together with the students; the third is the conclusion that the students must make on their own" [9, p. 167].

The method of running forward and returning to what has been learned, or the method of perspective and retrospect in the learning process allows establishing a connection between the topics of the program, forming holistic view of music in students [1, p. 135].

The method of musical generalization is a leading method of organizing music lessons. This method is aimed at mastering the students' key knowledge about music embodied in the topics of the program, the artistic thinking formation. As well as, it is embodied in achieving the integrity of the lesson based on the topic of the semester [6, p.140].

A method of compositions creating aimed at combining different forms of communication between students and music while performing one work [8, p. 145].

The method of creating an artistic context, aimed at the development of musical culture of contemporary students through integration with other related types of art, history, life situations, creation of artistic and pedagogical environment. This method makes it possible to represent music in the richness of its various connections. It helps to understand the similarity and difference from other types of art, other spheres of public consciousness [9, p. 154].

According to L. Shkolyar, the method of artistic and creative process modeling is aimed at increasing the active mastering of works of art. It is the method of modeling the artistic and creative process, when the student acts as the creator-composer, creatorpoet, creator-artist. The student who re-create a work of art for himself and other people. This is especially important when mastering great classical works that have always been intended for "listening"; it is also important to master folklore, when students are immersed in the birth of music. They create puzzles, sayings and proverbs on their own; it is also important while mastering (learning) any song and for instrumental music [8, p. 157].

The method of intonation-style achievement of music is focused on personal interpretation of the musical language. It involves a deliberate selection of works of different, national or epochal 
styles. Listening to the musical language of any composer creates a need for knowledge. At the same time, students, based solely on the intonation-like perception of music, carry out such an interpretation of such work, which characteristics are integrity and emotional expressiveness [8, p. 162].

In our opinion, it is conditioned the specificity of didactic methods by which music education in the modern school is carried out by need to organize music-creative and emotional-dramatic students' practice. This practice should be a lesson of modern technological and exciting, open up incredible opportunities for the students' communication by means of music. The choice of teaching music methods depends on its understanding.

The transition to a fundamentally new of music teaching method today requires the teacher to transform the system of methodological thinking. This process is quite complicated. It manifests both the inertia of thinking and the unwillingness or inability to adopt innovative methods of music pedagogy.

The choice and implementation of modern didactic methods of teaching music arts in practice depends on the pedagogical skill of the music teacher, his musical aesthetic and pedagogical preferences. Each teacher prefers a particular component of this structure: one focuses on vocal and choral work, the second focuses on engaging conversation and listening to music, the third focuses on instrumental music, and the fourth focuses on the study of musical literacy. But it is essential to agree with those teachers who organically blend modern, innovative forms of communication with students in the musical arts. Those who make sure that the modern student is able to communicate with music depending on their musical abilities and interests, as a result the student is pleased with such communication.

Conclusions and suggestions. Scientists confirm that modern man has become problematic, and therefore his education, upbringing and development cannotbeexplained by any method of monocentric approach. The consciousness of modern man is specified by the characteristics of the multidimensionality of its structures. It is developed as a result of the measurement dominance, given by the paradigm of nationalethnic culture, which carries a semantic image of modern man.

Thus, considering some aspects of students' music education at the present stage, as well as the experience of specialists, we can conclude the following: the peculiarity of modern pedagogical concepts and methods of students' music education is to focus on musical education. This education underlies the principles of collective music enriched with innovation achievements; the most progressive and modern ideas about the development of musical abilities, musical culture, artistic taste of students at the present stage of our lives.

Further scientific research requires the essential features of the formation of a modern lifecreating educational space of national education. It also requires new modern approaches to the activation of pedagogical creativity of the teacher of music, methods, techniques and means of creative pedagogical activity. Such activity that will significantly enable and facilitate the education.

\section{References:}

1. Абдуллин Э.Б. Теория музыкального образования: Учебник для студ. высш. пед. учеб. заведений. Москва : Издательский центр «Академия», 2004. 336 с.

2. Асафьев Б.В. Избранные статьи о музыкальном просвещении и образовании. Ленинград, 1973. $151 \mathrm{c}$.

3. Выготский Л. Педагогическая психология. Москва : Педагогика, 1991. 480с.

4. Гончаренко С. Український педагогічний словник. Київ : Либідь, 1997. 376с.

5. Зязюн І.А. Педагогіка добра: ідеал і реалії : наук.-метод. посіб. Київ : МАУП, 2010. 312 с.

6. Масол Л.М., Гайдамака О.В., Бєлкіна Е.В., Калініченко О.В., Руденко І.В. Методика навчання мистецтва у початковій школі : посібник для вчителів Харків : Веста. Видавництво «Ранок», 2006. 256 с.

7. Медушевский В. Онтологические основы интерпретации музыки. Интерпретация музыкального произведения в контексте культур. Москва, 1994. С. 3-10.

8. Музыкальное образование в школе : учебное пособие / Под ред. Л.Школяр. Москва : Издат. Центр «Академия», 2001. 232 с.

9. Олексюк О.М. Музична педагогіка : навч. посіб. Київ, 2006. 188 с.

10.Печерская Е.П. Уроки музыки в начальных классах: учеб. пособие. Москва:Просвещение, 2001. 272 c.

11. Ростовський О. Теорія і методика музичної освіти: навч.-метод. посіб. Тернопіль, 2011. $640 \mathrm{c}$.

12.Рудницька О.П. Педагогіка: загальна та мистецька : навчальний посібник. Тернопіль : Навчальна книга, Богдан, 2005.

13.Черкасов В.Ф. Теорія і методика музичної освіти : навч. посіб. Київ, 2016. 240 с. 


\begin{abstract}
Бухнієва О. А., Банкул Л. Д. Деякі методичні аспекти музичного навчання школярів на сучасному етапі

У статті розглядається проблема музичного навчання школярів на сучасному етапі в контексті виконання завдань реформування мистецько-педагогічної освіти. Ця проблематика порушується під час вивчення курсу “Методика музичного навчання" у вищих навчальних закладах, який введено в навчальний процес спеціалізації 014.13 Середня освіта. Музичне мистецтво. Розглянуто процес розуміння світоглядної цінності музичного мистецтва у світлі сучасних методичних аспектів музичної педагогіки та процес осмислення адекватності сучасного сприйняття музичного мистецтва учнями середньої школи. Доведено важливість синтезу усталених традицій музичного навчання з необхідністю переходу на принципово нову методику музичного навчання та виховання, яка сьогодні вимагає від учителя певної трансформації системи методичного мислення; досягнення розуміння учнями особливостей сучасної музичної мови і засобів музичної виразності; розуміння музичної інтонації як одного з найдісвіших засобів розкриття художнього образу твору. Доведено позитивний вплив класичної музики на формування особливих якостей сучасного учня, утворення в ньому системи музичних, мистецьких і загальнолюдських цінностей як визначальних чинників ставлення особистості до сучасного світу та відповідних визначеним ціннісним орієнтирам способів поведінки і життя у світі.

На основі аналізу деяких методичних аспектів музичного навчання школярів на сучасному етапі мистецько-інфоормативну компетентність розкрито як один із найважливіших способів художньо-профресійного рівня учителя.

Встановлено, що основні завдання інноваційного підходу до методичних аспектів музичного навчання школярів полягають у постійному пошуку і впровадженні нових максимально ефективних технологій музично-педагогічної дидактики. Важливою умовою, від якої залежить реалізація сучасних музично-педагогічних аспектів навчання школярів, є інноваційний потенціал учителя музичного мистецтва, який полягає у здатності створювати, сприймати, реалізовувати нововведення і своєчасно позбавлятися застарілих, педагогічно недоцільних методів навчання і виховання.
\end{abstract}

Ключові слова: сучасні музично-педагогічні аспекти навчання, методи навчання і виховання, музично-виховна робота. 